CATALAN REVIEW

Catalan Review

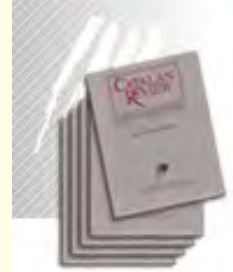

You are accessing the Digital Archive of the Catalan Review Journal.

By accessing and/or using this Digital Archive, you accept and agree to abide by the Terms and Conditions of Use available at http://www.nacs-

catalanstudies.org/catalan review.html

Catalan Review is the premier international scholarly journal devoted to all aspects of Catalan culture. By Catalan culture is understood all manifestations of intellectual and artistic life produced in the Catalan language or in the geographical areas where Catalan is spoken. Catalan Review has been in publication since 1986 .
NORTH

AMERICAN

CATALAN

SOCIETY
Esteu accedint a l'Arxiu Digital del Catalan Review

A l' accedir i / o utilitzar aquest Arxiu Digital, vostè accepta i es compromet a complir els termes i condicions d'ús disponibles a http://www.nacs-

catalanstudies.org/catalan review.html

Catalan Review és la primera revista internacional dedicada a tots els aspectes de la cultura catalana. Per la cultura catalana s'entén totes les manifestacions de la vida intel lectual i artística produïda en llengua catalana o en les zones geogràfiques on es parla català. Catalan Review es publica des de 1986.

\title{
Nationalism and Language in Catalan and Irish Contemporary Short Stories: Feminist and Postcolonial Perspectives Irene Boada
}

Catalan Review, Vol. XII, number 1 (1998), p. 9 -21 


\title{
NATIONALISM AND LANGUAGE IN CATALAN AND IRISH CONTEMPORARY SHORT STORIES: FEMINIST AND POSTCOLONIAL PERSPECTIVES
}

\author{
IRENE BOADA
}

Sometimes, as I sat in the Biblioteca de Catalunya in the 14thcentury hospital building, I had to blink to make sure that I was not in the National Library in Dublin.

Colm ToIBIN ${ }^{1}$

The point is rarely made, but Catalonia and Ireland possess striking similarities in terms of their socio-cultural development. Both were colonial societies at one time or other; both are, or have been bilingual; both existed in the shadow of a political and cultural giant; both responded to this position of cultural subordination in literature as well as in politics; and both of course experienced a cultural revival during the second half of the nineteenth century. In each case literature was exploited in the service of a nationalist ideology. Good examples are the popular poems "A Nation Once Again", by Thomas Davis, and the ode "La Pàtria" [The Fatherland], by B.C. Aribau, written independently of each other but produced in the same years (I830s). It is remarkable also how the role of these turbulent nationalities has been labelled in almost identical terms by the metropolitan centres of power, in Madrid and London respectively, as the Catalan/Irish "problem". Moreover, within each society, there has been a fair degree of self-questioning which runs along roughly parallel lines. What does Irishness mean? What does it mean to be Catalan, both in the past and in the present? In the literature, problems of identity are reflected in problems of definition and classification. Is Anglo-Irish literature Irish? Can writings in Spanish, by Catalan writers, be regarded as truly Catalan? There are also differences, of course. In the Catalan case the indigenous language survived, and now flourishes, and has long been the primary marker of identity. In the Irish case the Irish language has been largely lost, and religious affiliation has been a more important sign of ethnic identity.

There is a further difference which tends to set the countries apart, one which is of basic importance to cultural production. This is the matter of the language spoken and its place in the global system of

${ }^{1}$ Colm Toibin, "Playboys of the GPO," London Review of Books 18 Apr, 1996; 14 
communication and commerce. English is now the most powerful language in the world, whereas Catalan is a minority language in Europe with, at most, some 9 million speakers. Being able to publish in one or the other language obviously makes a difference. The opportunities for publishing in English are much greater, and the potential rewards greater still.

The concerns of this paper are colonialism, nationalism and language, as reflected in contemporary short stories written by women in Catalonia and Ireland. ${ }^{2}$ The theoretical perspectives I bring to bear, in interrogating and illuminating these texts, are postcolonialism and feminism. ${ }^{3}$ While these have found their way, to varying degrees, into literary criticism in Ireland, their application is relatively underdeveloped in the Catalan case. For this reason alone, it makes sense to place the primary emphasis on Catalan short-story writing. Of course the choice of these bodies of theory dictates the agenda to some extent. Thus, in this paper there is special attention to the role of women in postcolonial societies, and their troubled relationship, not only to nationalism but to language as well.

By fusing postcolonial and feminist perspectives, it is possible to discern certain parallels between the role of women and the position of subjects in colonial countries. Both share a subservient status within the society in which they find themselves. They each possess the characteristic of 'otherness' Their minds, some would argue their very psychology, are dominated and colonised by male power systems and imperious male modes of thought. In fact, there is a case for saying that Catalan and Irish women are doubly colonised: both by reference to their status as women and by reference to their nationality. Women writers in Catalonia and Ireland have used literature to question both types of oppression.

Both postcolonial and feminist theories usefully alert us to the

${ }^{2}$ Only a very truncated view can be offered here. These and other themes are developed more fully in my unpublished doctoral thesis: 'Women Write Back': A Study of Contemporary Irish and Catalan Short Stories (University of Ulster, ig98).

${ }^{3}$ For good general introductions to postcolonial thought see Bill Ashcroft, Gareth Griffiths and Helen Tiffin, The Empire Writes Back. Theory and Practice in Post-colonial Literatures (London: Routledge, 1989); - The Post-colonial Reader (London: Routledge, 1995). Works on feminism in the context of literary criticism are legion. The following proved particularly useful for this particular study: Helene Cixous, "The Laugh of the Medusa." Feminisms. An Anthology of Literary Theory and Criticsim. Eds. Robyn R. Warhol and Diane Price Herndl. (New Brunswick: Rutgers University Press, 1993); Sandra Gilbert, and Susan Gubar. The Madwoman in the Attic: The Woman Writer and the Nineteentb-Century Literary Imagination. and ed. (New Haven: Yale University Press, 1980); bell hooks, "Marginality as a Site of Resistence." Out There: Marginalization and Contemporary Culture. Eds. Russell Ferguson et al. (Cambridge, MA: The Met Press, 1990). CL Innes, Woman and Nation in Irish Literature and Society 1880-1935. (New York: Harvester Wheatsheaf, 1993). 
subtle forms oppression can take and, in particular, how it affects the confidence of the oppressed. Geraldine Moane has studied how the mechanisms of domination become institutionalised over time and it becomes difficult for both the dominants and the subordinates to recognise them. She adds: "If these mechanisms are working well, they not only succeed in keeping the subordinates convinced that they deserve their position, or that, indeed, their subordination is natural and actually good for them".4

A number of literary critics have linked colonialism with masculinity. They view the phenomenon of colonialism as a product of an imbalanced situation, wherein masculinity is associated with activity, strength and power. Femininity, on the contrary, has connotations of powerlessness. This kind of imagery is present in Seamus Heaney's "Act of Union" in which the Act of Union of 1800 is seen as a violation and described with arrogance by the coloniser. In this case, the speaker is male and the coloniser England: "I am still imperially/Male". Heaney goes on to present colonisation as a form of rape with long lasting consequences: "No treaty/ I foresee will salve completely your tracked/ And stretchmarked body, the big pain/ That leaves you raw, like opened ground, again".s

Ashis Nandy holds a similar opinion about gender imbalance: Colonialism, too, was congruent with the existing Western sexual stereotypes and the philosophy of life which they represented. It produced a cultural consensus in which political and socio-economic dominance symbolised the dominance of men and masculinity over women and femininity. ${ }^{6}$ One would of course add that colonial structures are not a necessary condition for male dominance, as this has a more universal character.

Albert Memmi explains how the colonised become objectified: What is left of the colonized at the end of this stubborn effort to dehumanize him? He is surely no longer an alter ego of the colonizer. ${ }^{7}$ $\mathrm{He}$ is hardly a human being. He tends rapidly toward becoming an object. As an end, in the colonizer's supreme ambition, he should exist only as a function of the needs of the colonizer Memmi goes further. The colonised end up accepting the vision the coloniser has of themselves, that is their own second-class condition and, rather than

4 Geraldine Moane, "Legacies of Colonialism for Irish women. Oppressive or Empowering?" Irish Journal of Feminist Studies March, 1996, 47.

s Seamus Heaney, North (London: Faber and Faber, 1978) 49-50.

${ }^{6}$ Ashis Nandy, The Intimate Enemy. Loss and Recovery of Self Under Colonialism (Delhi: Oxford Universicy Press, 1992) 4.

7 Albert Memmi, The Colonizer and the Colonized (London: Earthscan Publications, I990) I52. 
hating the coloniser, paradoxically, they feel guilty about themselves and come to admire their oppressor:The accusation disturbs him and worries him even more because he admires and fears his powerful accuser. 'Is he not partially right?' he mutters. 'Are we not all a little guilty after all? Lazy, because we have so many idlers? timid, because we let ourselves be oppressed.' Wilfully created and spread by the colonizer, this mythical and degrading portrait ends up by being accepted and lived with to a certain extent by the colonized. ${ }^{8}$

In a similar way, as a consequence of the male gaze, women have problems accepting their own bodies and, for instance, cannot face themselves in the mirror. We have several examples of this phenomenon. In Maria Mercè Marçal's "Joc de màscares" [Masks game], Laura has a strong dislike for mirrors. ${ }^{9}$ She keeps repeating that she does not like mirrors. The mirror is also an important element in Mercè Rodoreda's writing. In "Abans de morit" [Before dying], when Marta is wearing her wedding dress, she looks at her reflection in the mirror and sees a ghost. ${ }^{10}$ Her marriage eventually fails and she decides to commit suicide. Glancing in the mirror, she catches a glimpse of her own reflection and sees a ghost once more. ${ }^{\text {I }}$ Being powerless, she says she feels sorry for the girl who is going to die. The end of "L'airet del mati, a Barcelona" [The fresh morning air, in Barcelona] is about Teresa looking at her own naked body in the mirror. Teresa cries because she feels old, fat and ugly. She says she feels defeated. ${ }^{12}$ The mirror image appears in some Irish stories as well. For example, Finnula, in "Naming the Names", asks her partner to cover all the mirrors in the house. ${ }^{13}$ Moreover, women often feel guilty about their "failings" and their sense of inferiority, sometimes even in extreme situations, such as after having been beaten by their husbands. There are many examples of women loving men so much that they continue to endure nightmares, being reluctant or afraid to leave the relationship. They see men as more powerful than themselves. Following Albert Memmi's suggestive terms, we may speak of "the colonised who accept".

In postcolonial discourse the word "decolonisation" is often used

${ }^{8}$ Albert Memmi 53 .

9 Maria Mercè Marçal, "Joc de màscares," Dones soles (Barcelona: Planeta, 1995), 8I82,86 .

10 Mercè Rodoreda, *Abans de morir, Vint-i-dos contes (Barcelona: Selecta, 1989) 268 ,

"Rodoreda, *Abans* 288.

12 Simó 199.

13 Anne Devlin, «Naming the Names, The Way-Paver (London: Faber and Faber, 1986) II6. 
to refer to the period between the achievement of independence and the present. Colonisation is an integral part of the history of many countries, a phase which in the end has to be transcended. Because colonies are created through violence, the eventual consequences are likely to be not only malign but also complex. During the beginning of the nationalist movements in Ireland and Catalonia in the middle of the nineteenth century, there was a strong admiration for, even idealisation of the period before colonisation, in particular the middle ages, when the language and the culture were strong and confident. The recovery of the language, for example, was considered essential. By contrast, women could never go to a "before" period, as a reference point, because they have always been colonised and this is a fundamental difference from postcolonial countries. Achievement of liberation for women is, therefore, more complex. However, through their writing they are trying to find new languages and new realities in which they feel more comfortable. For example, the exploration of female sexuality is also a desire to find essence, authenticity and comfort. About her poetry, Medbh McGuckian says: "It's mostly moody and menstrual in a way a man's poetry never is." "I4

Traditionally, men have greatly valued possession and, in particular, possession of territories. History is full of wars driven by the desire to annex territory, resources and people. In the typical case this involves massive killings, sexual abuses and the imposition of new ruling systems. Traditionally, women have been excluded from such acts of possession. Enclosed in their primary activity of caring and motherhood, they have developed an attitude of giving rather than taking. Incidentally, the word "possession" is often used by men to describe sexual relationships, a usage rejected by women writers, because of its connotations of conquest and even rape. Many short stories by Irish and Catalan women writers focus on outcasts. For example, Caterina Albert's "La vella" [The old woman] is about the marginalisation and neglect of an old woman by her relatives. The result is that she is later burned in a fire. Mercè Rodoreda's "Ada Liz" is the story of the dilemmas and loneliness of being a prostitute. In several stories by Carme Riera and Isabel-Clara Simó, the handicapped, the defeated and children are the protagonists. Edna O'Brien's "Dramas" is about the nightmare of a gay shop owner in an Irish community. Fiona Barr's "Sun and Shadow" centres on the problems of a handicapped boy. By extension, it could be argued that these writers' interests in marginalised characters may also be seen to be interactively related to a concern with colonised countries, in this case, Ireland and Catalonia.

14 Maeve McGuckian I. 
It is hardly possible, at least in this century, to speak of colonialism without introducing nationalism. The two intersect, while feminist perspectives cross-cut each. Women have engaged with Catalan and Irish nationalisms. Although important in their writing, it needs to be said immediately that nationalism is not the first priority of most Irish and Catalan women writers. More significant for many is the task of "decolonising" themselves, that is, of constructing a new gender identity. Anne Charlon has noted:

De fet, tot i que la lluita catalanista serveix de base a tota l'obra de les novel.listes, no en constitueix pas el tema essencial, ni el més aparent. En canvi, la condició femenina, l'experiència femenina, els desigs de les dones i allò que elles refusen, són omnipresents en la literatura femenina catalana.

Despite the fact that Catalanist struggle is a basis in all the work of the female novelists, it is not the principal subject, nor the most apparent. However, the feminine condition, the feminine experience and women's wishes and also what they refuse are omnipresent in female Catalan literature. $]^{15}$

Like most ideologies, nationalism is patriarchal. Its romantic inspiration created the vision of Ireland/Catalonia as a weak and passive woman in need of help and salvation such as the figures of Teresa in Eugeni d'Ors's La ben Plantada and Yeats's Cathleen Ni Houliban show. In Ireland, once the new Irish Free State was created, women were shut out of an active role in politics. De Valera's Ireland, with its emphasis on Catholicism, was very much male-centred, though in truth this represented continuity rather than change in Irish society. While women writers show themselves to be critical of a heritage of colonial domination in both societies, they are less than sentimental about purely nationalist concerns. Still, there is a sympathy with the nationalist cause, in its political or cultural manifestation, or both, because they are also "colonised".

Most of contemporary Catalan and Irish women writers are opposed to violence. They are strongly critical of violence in Northern Ireland, the violence of the Spanish Civil War and the Second World War. They reject the intolerance born of masculinist ideologies, including nationalism. A woman in one of Rodoreda's stories says: "Tot el món ... és ple de guerres i els homes embogeixen per anar a la guerra" [All the world is full of wars and men are crazy to go to war]. ${ }^{16}$ Women reject the symbols of bigoted nationalism and war: flags,

15 Anne Charlon, La condició de la dona en la narrativa femenina catalana (19oo1983) (Barcelona, Edicions 62, 1990) 12. Moreover, since many barriers have been placed in the way of women's participation in politics, so their interest in nationalism has been "at a distance".

${ }^{16}$ Rodoreda, Viatges, I5. 
military music, party emblems, just as some reject the symbols of traditional marriage (as we have seen in chapter two). They prefer a much more open idea of nationalism, just as they like to think of gender roles in a much more open way.

One of the worst consequences of colonialism is the loss of the indigenous language. Postcolonial theory highlights what happens when a community loses its most important means of communication: the language and its associated cultural heritage. The loss of the language gives rise to a lack of personal and communal confidence. This is a common feature among postcolonial peoples. Most Catalan women writers have chosen to use the Catalan language at times when it was difficult to get published and not prestigious. ${ }^{17}$ Writting in Catalan was the best writers could do for the national cause considering that, due to the abnormality of the culture, there was a need to produce in Catalan and also because the access to political life was difficult for women. As a consequence, feminist, linguistic and nationalist vindications have been deeply mixed.

Even if the Irish language is almost gone, some Irish women writers, like Catalan writers, prefer their native language, in this case Irish, as a vehicle for their writing. That is the case of the poet Nuala Ni Dhomhnaill, who celebrates writing in Irish and finds Irish less phallogocentric than English. She makes the point that the Irish language and women have been oppressed in a similar way. She says:

I think I'm very lucky in being Irish because the Irish language wasn't industrialised or partriarchalised. And many things, including this idea of a deeper quality, this negative femininity, this Hag Energy, which is so painful to mankind, hasn't been wiped from our consciousness, as it has in most cultures. Irish in the Irish context is the language of the Mothers, because everything that has been done to women has been done to the Irish. ${ }^{18}$

At the end of 1970s, Isabel-Clara Simó published a collection of short stories, És quan miro que bi veig clar [It's when I look that I can see clearly], paraphrasing a famous Catalan poem "És quan dormo que hi veig clar" [It's when I sleep that I can see clearly]. Simó is passionately concerned with the fate of the Catalan language. The stories are about the process of the recovery of the Catalan language and culture which was actually taking place at that moment, after Franco's death in 1975. By then, many Spanish words had entered the Catalan language and Catalan linguists insisted on recovering the old

${ }^{17}$ Ana María Moix or Esther Tusquets, for instance, are exceptions.

${ }_{18}$ Ann Owens Weekes, Unveiling Treasures. The Attic Guide to The Published Works of Irish Women Literary Writers. Drama, Fiction, Poetry (Dublin: Attic Press, 1993) 253 . 
Catalan words and making a collective effort to use them. This was difficult. People in Catalonia had been denied access to their native language in the schools and colleges, hence many had low standards of literacy in Catalan. Through the medium of the short stories, Simó demands flexibility for people to change the language. Simó brings to life the language enthusiasm of these transitional years, of people correcting each other in speech as part of the great collective effort to rehabilitate Catalan. Some of the stories illustrate the tensions which surrounded the struggle between Catalan and Spanish. These have social class as well as ethnic dimensions. Thus, in "Em dic Jaumet" [My name is Jaumet] Jaumet's mother, because she wishes to rise in the social scale, seeks to cast aside the cultural baggage of lower-status Catalan. She begins to speak Spanish to her child, even renaming him Jaime (the Spanish version of his name). However, the child resists and does not want to use the Spanish language.

These various individual and collective acts are perceived by Simó as nationalistic, and the stories exude a sense of the necessity of remaking Catalan culture and politics in the aftermath of Francoism. There is also a palpable love of Barcelona. For Simó, Barcelona is the most beautiful city in the world:

L'aire del matí, a Barcelona, és la cosa més bonica del món. La gent va atrafegada, però d'una manera estimulant. El sol entra oblic per la mar i es veu que porta una càrrega d'oxigen que ho anima tot, i ens amara el cos de vitalitat i de ganes de fer coses... De vuit a nou del mati, Barcelona és la ciutat més bonica del món."

[The fresh air, in Barcelona, is the most beautiful thing in the world. People are busy but in a pleasant way. The sun gets into the sea obliquely and infuses a huge amount of oxygen which regenerates everything, and gives us vitality... From eight to nine in the morning, Barcelona is the most beautiful city in the world. $]^{19}$

Moving forward in time to the I990s, nationalist-type concerns are less to the fore than in the period of euphoria surrounding the early days of democratisation. But in "L'empelt" [The graft], by Maria Angels Anglada, the old theme of the fortunes and prospects of the Catalan language springs afresh. The story is initially framed against the background of the death of another Latin language-Dalmatianwhich became extinct towards the end of the nineteenth century. In "L'empelt" only one woman on the island home of the language is still able to speak Dalmatian. She is old. She is going to die soon. With her passing, the language will also die. The death of the language will change the world, its landscape and nature:

19 Simó, "L'airet" 168-169. 
Els penya-segats ja no seran els mateixos, sense ella, ni ho serà la plata de les oliveres, ni els peixos diferents que bullen a les xarxes en la darrera agonia, ni serà igual l'escassa pluja ni el cop d'ala de cada vent, de cada ocell. [The cliffs won't be the same, without it, nor the silver of olive trees, nor different fishes which twist in the nets in their last agony, nor the light rain, nor the movement of the wings of every bird $]^{20}$

The story then takes a futuristic shift, and we find ourselves in the twenty-first century. Many minority languages are disappearing world-wide, threatened by the dominance of English and AngloAmerican culture. Latin languages find themselves under particular threat. A Dutch linguist, Ernst Heyltjes, whose favourite language is Catalan, travels to Catalonia to help save the language. There has been a coup d'etat whose main aim is to extinguish the Catalan language. (The echoes here of the Francoist era are deliberate.) Elsewhere in Europe there have been strong cultural revivals; in the case of Wales, this long-submerged nation has even achieved political independence. But in Catalonia the native language was facing extinction. The Dutch linguist finds a Catalan shepherd, Jordi, who happens to be the last native speaker of Catalan. Finding Jordi had not been easy. The visit had to be in secret as the Central government no longer allowed the study of Catalan. Listening, enraptured by the speech he is recording, the Dutchman feels there is no music as beautiful as the sound of those romantic words. But the political reality is harsh in the extreme.

durant anys i panys s'havien perseguit, empresonat, mort, els parlants obstinats. En altres casos, tècniques de rentat de cervell, individuals i col-lectives, esporàdiques $i$ continuades, havien estat emprades amb eficàcia.

[for many years, Catalans who had obstinately clung to the language had been persecuted, imprisoned, killed. In other cases, at the level of individuals and groups, sporadic and continuous techniques of brainwashing had been used effectively]. ${ }^{21}$

Driving along Catalan roads, the Dutch linguist finds police checkpoints all over the place. Suddenly he is kidnapped by a group of Catalans. He discovers that they are part of a resistance movement against the new regime and are trying to maintain the Catalan language underground. The eventual outcome is not important to the point being developed here. What matters is that the author, Maria Angels Anglada, is touching on deep anxieties in Catalan society regarding the survival of the language. Is the living language of Catalonia facing

${ }^{20}$ Maria Angels Anglada, La daurada parmèlia i altres contes (Barcelona: Columna, I991) 12.

${ }^{21}$ Anglada, 18. 
death in the future? If, so what of the riches of Catalan literature and culture, which may also disappear with the spoken tongue? Unlike the Irish case, the centrality of the native language to a sense of cultural and national identity is underlined.

Any language, in the view of some feminists, is foreign to women. It belongs to the coloniser, that is men. Lacking a "native tongue" and in search of it, French feminists seek women's essence in their sexuality, which they call the "jouissance", the re-experience of the physical pleasures of infancy which have been systematically repressed. Women have not been able to express their own sexuality fully because they have been mere objects of male desire (virgins or prostitutes, wives or mothers). Hence, women need new and nonphallogocentric languages to be able to express themselves. Women's uneasy position in relation to language leads to frustration. Yet it might be helpful to them to play around with language. Richard Kearney has suggested that James Joyce's uneasiness with the English language may account for his exceptional capacity to deconstruct and reconstruct it. ${ }^{22}$ Women, who are somewhat similarly situated, may be in a position to turn these tensions to creative advantage. So the problem is not so much with the language per se, as with how the English language is used. Toni Morrison has suggested that a marginal position allows deeper insight: "I think the range of emotions and perceptions I have had access to as a black person and a female person are greater than those who are neither. ${ }^{23}$

From a feminist perspective we can say that a consequence of phallogocentrism is that for the woman writer words sometimes are not available to define women's experiences. Toril Moi comments on this phenomenon within the specific context of placing labels or names on life experiences:

One specific argument within the study of sexism in language is the question of naming. Feminists have consistently argued that those who have the power to name the world are in a position to influence reality...It is argued that women lack this power and that, as a consequence, many female experiences lack a name. ${ }^{24}$

For example, in Eilis Ni Dhuibhne's "The Inland Ice", Polly, an unhappy wife, feels confused. She knows that there is beauty inside

${ }^{22}$ Richard Kearney, ed., The Irish Mind: Exploring Intellectual Traditions (Dublin: Wolfhound Press, 1985-1987) is.

23 Toni Morrison, "Interview with Toni Morrison 'Voice of America" The Irish Times 28 March (1998): I6.

${ }^{24}$ Toril Moi, Sexual/Textual Politicsi Feminist Literary Theory (London: Routledge, 1994) 158-159. 
her but she cannot enjoy it. She describes the inner part of an icecap in Greenland as if she was describing the inner part of herself: "Underneath, however, the ice has formed shapes like stalagmites, and when you peer under you see that they are blue and turquoise, silver, jade, and other subtle, shining, winking colours for which you have no name." 25 They have beautiful colours but they are known only by analogy, they have no name like the many parts of her being which have no name. There is no language to describe the hidden/ beautiful/ female parts of herself. In Ni Dhuibhne's "The Shapeshifters", Angela's mother does not know the names "for the intimate parts of the body, the intimate details of sexuality" because they are "dirty and taboo". ${ }^{26}$ We have a similar example in Montserrat Roig's "Mar" $[\mathrm{Mar}] .{ }^{27}$ The nameless protagonist cannot find a word to describe a love relationship she had with a woman called Mar:

No ha estat escrita la paraula que defineixi el que va néixer el dia en què la vaig veure per primera vegada... i tampoc jo sóc capaç d'inventar-ne una. [The word which defines what was born the day I saw her for the first time has not yet been written... and neither am I able to make one up. $]^{28}$

By contrast, men are quick to name things, and are particularly adept at making up crude words and phrases which serve to marginalise or humiliate women. This of course extends to the invention of pejorative words and phrases which stigmatise relationships between women.

Later the protagonist says: "No m'adonava, aleshores, que hi ha una barrera, més enllà dels diners, més enllà de les idees, i que aquesta barrera és la del llenguatge." [I didn't realise, then, that there is a barrier, beyond money, beyond ideas, and that this barrier is the one of language. $]^{29}$

It is time to draw some of these threads together. The Catalan and Irish women writers discussed here may be said to engage with nationalism while at the same time rejecting masculine constructions of nationalism. To take a particularly important example from the realm of national image making, most of these writers reject the personification of the nation as a passive woman -she who has to be saved or died for. It is instructive to be reminded that even when

${ }^{25}$ Eilis Ni Dhuibhne, "The Inland Ice," The Inland Ice and Other Stories (Belfast: The Blacstaff Press, 1997) 217.

26 Ni Dhuibhne, "The Shapeshifters," Eating Women Is Not Recommended (Dublin: Attic Press, 1991) 112.

27 Mar has two meanings in Catalan: a woman's name and sea.

${ }^{28}$ Montserrat Roig, "Mar," El cant de la joventut (Barcelona: Edicions 62, 1989) 48.

${ }^{29}$ Roig, "Mar" 58. 
independence or autonomy is achieved, postcolonial countries continue to marginalise groups such as women. Eamon de Valera, the puritanical father figure of the modern Irish state, famously remarked on the eve of political emancipation: Labour must wait. Significantly, it wasn't even necessary to add: Women must wait.

The relationship between women writers and nationalism is a complicated one, and one must be cautious about generalising, not just between two societies but even within the same society. Edna O'Brien, for instance, who is overtly nationalistic in her public statements, represents the concerns of nationalism and nationality (as well as women) in a very different way to that of a younger writer like Maeve Kelly. There are differences of emphasis also among Catalan women writers. Still, there are commonalties. On the basis of the short stories examined here, one may conclude that the authors are drawn to a liberal nationalism: one which is open, inclusive, and recoils from violence. To use a contemporary political reference point, this could be the core statement of the Northern Ireland Women's Coalition, formed in 1996 to promote new values and new approaches within the male bearpit of Northern politics. It is also clear that woman writers eschew sexist images of the nation as presented in predominantly male discourses on nationalism. Issues of nationalism are configured differently.

In relation to language, it is difficult to dissent from Thomas Davis' view that losing the most precious sign of cultural identity for a community, that is, its language, means losing an important part of its roots. The imposition of the coloniser's language guarantees longterm colonisation and makes decolonisation more difficult. That has been one of the greatest cultural difficulties Ireland has had to go through. The ambivalence of various Irish women writers in relation to the Irish language suggests the complexity of the question. The situation in Catalonia, at least on the surface, is more clear cut. Despite the historic banning of the Catalan language, Catalonia has managed to maintain its language, at least until now. However, being placed formally in the same position as the powerful Spanish language means, in effect, "competing" with it. As a result, some linguists have grave forebodings regarding the future viability of Catalan, despite a partlyfavourable state framework for its development in recent times.

Questions of language and the women's question are closely connected. Women find themselves using a 'foreign' tongue. ${ }^{30}$ In the light of feminist critical theory, one might suggest that women writers experience frictions or difficulties in being obliged to work within a

30 How Ulster unionist women might relate to, or dissent from this statement would itself contitute an interesting point of departure for some further research. 
phallogocentric language order. To achieve greater authenticity, it seems necessary to "decolonise" it first. That is one of the most difficult challenges women writers have to face, not just in Ireland or Catalonia but wherever women put pen to paper. So, in many of the short stories we find women, especially younger writers, trying to use language in ways that allow them to subvert a phallogocentric system. Paradoxically, the less centred position of women seems to facilitate artifice and wit. Indeed, there may be some similarities between the way Irish writers in English have successfully adapted and domesticated the language of the former colonial power for their own needs and the way women writers are revising and re-visioning the English language. In this respect, Catalan women writers, who are deprived of the huge dynamic of the Anglo-American literary industry and its associated literary studies, are lagging behind.

IRENE BOADA UNIVERSITY OF ULSTER 